(c) American Dairy Science Association, 2003.

\title{
Alternatives to Linear Analysis of Energy Balance Data from Lactating Dairy Cows
}

\author{
E. Kebreab, ${ }^{\star}$ J. France, ${ }^{\star}$ R. E. Agnew,† T. Yan,† M. S. Dhanoa,‡ J. Dijkstra,§ \\ D. E. Beever, ${ }^{\star}$ and C. K. Reynolds ${ }^{\star, 1}$ \\ *School of Agriculture, Policy and Development, The University of Reading, \\ Earley Gate, Reading RG6 6AR, United Kingdom \\ †The Agricultural Research Institute of Northern Ireland, \\ Hillsborough, Co. Down, Northern Ireland BT26 6DR, United Kingdom \\ \#Institute of Grassland and Environmental Research, Plas Gogerddan, \\ Aberystwyth, Dyfed SY23 3EB, United Kingdom \\ $\S$ Animal Nutrition Group, Wageningen Institute of Animal Sciences, \\ Wageningen University, Marijkeweg 40, \\ 6709 PG Wageningen, The Netherlands
}

\begin{abstract}
The current energy requirements system used in the United Kingdom for lactating dairy cows utilizes key parameters such as metabolizable energy intake (MEI) at maintenance $\left(\mathrm{ME}_{\mathrm{m}}\right)$, the efficiency of utilization of MEI for 1) maintenance, 2) milk production $\left(k_{l}\right), 3$ ) growth $\left(k_{g}\right)$, and the efficiency of utilization of body stores for milk production $\left(k_{t}\right)$. Traditionally, these have been determined using linear regression methods to analyze energy balance data from calorimetry experiments. Many studies have highlighted a number of concerns over current energy feeding systems particularly in relation to these key parameters, and the linear models used for analyzing. Therefore, a database containing 652 dairy cow observations was assembled from calorimetry studies in the United Kingdom. Five functions for analyzing energy balance data were considered: straight line, two diminishing returns functions, (the Mitscherlich and the rectangular hyperbola), and two sigmoidal functions (the logistic and the Gompertz). Meta-analysis of the data was conducted to estimate $k_{g}$ and $k_{t}$. Values of 0.83 to 0.86 and 0.66 to 0.69 were obtained for $k_{g}$ and $k_{t}$ using all the functions (with standard errors of 0.028 and 0.027), respectively, which were considerably different from previous reports of 0.60 to 0.75 for $k_{g}$ and 0.82 to 0.84 for $k_{t}$. Using the estimated values of $k_{g}$ and $k_{t}$, the data were corrected to allow for body tissue changes. Based on the definition of $k_{l}$ as the derivative of the ratio of milk energy derived from MEI to MEI directed towards milk production,

Received June 20, 2002.

Accepted December 27, 2002.

Corresponding author: E. Kebreab; e-mail: e.kebreab@reading. ac.uk.

${ }^{1}$ Present address: Department of Animal Sciences, The Ohio State University, OARDC, 1680 Madison Ave. Wooster 44691-4096.
\end{abstract}

$\mathrm{ME}_{\mathrm{m}}$ and $k_{l}$ were determined. Meta-analysis of the pooled data showed that the average $k_{l}$ ranged from 0.50 to 0.58 and $\mathrm{ME}_{\mathrm{m}}$ ranged between 0.34 and 0.64 $\mathrm{MJ} / \mathrm{kg}$ of $\mathrm{BW}^{0.75}$ per day. Although the constrained Mitscherlich fitted the data as good as the straight line, more observations at high energy intakes (above 2.4 $\mathrm{MJ} / \mathrm{kg}$ of $\mathrm{BW}^{0.75}$ per day) are required to determine conclusively whether milk energy is related to MEI linearly or not.

(Key words: energy metabolism, dairy cow, lactation)

Abbreviation key: BIC = Bayesian information criteria, $\mathbf{E}_{\mathbf{l}}=$ energy in milk (MJ/d), $\boldsymbol{k}_{\boldsymbol{g}}=$ the marginal efficiency of utilization of MEI for growth, $\boldsymbol{k}_{\boldsymbol{l}}=$ the marginal efficiency of utilization of MEI for milk production, $\boldsymbol{k}_{\boldsymbol{m}}$ $=$ the marginal efficiency of utilization of MEI for maintenance, $\boldsymbol{k}_{\boldsymbol{t}}=$ the marginal efficiency of utilization of body stores for milk production, $\mathbf{M B W}=$ metabolic body weight $\left(\mathrm{kg}^{0.75}\right), \mathbf{M E}=$ metabolizable energy, $\mathbf{M E I}=\mathrm{ME}$ intake (MJ/kg $\left.{ }^{0.75} / \mathrm{d}\right), \mathbf{M E}_{\mathbf{m}}=\mathrm{ME}$ requirement for maintenance $\left(\mathrm{MJ} / \mathrm{kg}^{0.75} / \mathrm{d}\right), \mathbf{T}_{\mathbf{g}}=$ tissue gain $\left(\mathrm{MJ} / \mathrm{kg}^{0.75} / \mathrm{d}\right), \mathbf{T}_{\mathbf{l}}$ $=$ tissue loss $\left(\mathrm{MJ} / \mathrm{kg}^{0.75} / \mathrm{d}\right)$.

\section{INTRODUCTION}

The metabolizable energy (ME) feeding system for ruminants, developed by Blaxter (1962), was first proposed for use in the United Kingdom by the Agricultural Research Council (ARC, 1965). A simplified system, based on these proposals, was subsequently recommended for adoption by the Ministry of Agriculture, Fisheries and Food (England and Wales). The original system (ARC, 1965) was revised substantially by ARC (1980), modified further by the Agricultural and Food Research Council (AFRC, 1990), and a new working version published in 1993 (AFRC, 1993). Key parameters in the current ME system for lactating dairy cows are: net energy requirement for maintenance $\left(\mathbf{M E}_{\mathbf{m}}\right)$; 
the efficiency of utilization of ME for 1) maintenance $\left.\left(\boldsymbol{k}_{\boldsymbol{m}}\right), 2\right)$ milk production $\left(\boldsymbol{k}_{\boldsymbol{l}}\right)$, and 3) growth $\left(\boldsymbol{k}_{\boldsymbol{g}}\right)$, and the efficiency of utilization of body stores for milk production $\left(\boldsymbol{k}_{t}\right)$. These values were determined largely using linear regression methods to analyze energy balance data from calorimetry experiments.

Over the last two decades, a considerable volume of research on the energy metabolism of dairy cows has been undertaken in the United Kingdom. These studies have highlighted a number of concerns over the current energy feeding system, particularly in relation to values for the aforementioned key parameters (Agnew and Yan, 2000). Underlying these concerns could be the rigid acceptance of linear methods in analyzing energy balance data.

The rate of energy retention by the growing ruminant is nonlinearly related to its level of ME intake (MEI) over the range of ingestion, as successive increments in daily intake at high intake levels produce progressively smaller increments in daily energy retention as body tissue. Blaxter and Wainman (1961) approximated this nonlinear relationship with two straight lines intersecting at zero energy retention (i.e., maintenance) for growing ruminants. The slope of the linear equation below maintenance gives the efficiency of utilization of $\mathrm{ME}$ for maintenance, and the slope of the linear equation above maintenance gives the efficiency of utilization of $\mathrm{ME}$ for tissue energy. However, Blaxter and Boyne (1978) subsequently proposed the Mitscherlich equation for describing the relationship between tissue energy retention and MEI in growing ruminants, based on a detailed analysis of more than 80 calorimetry experiments with sheep and cattle. The Mitscherlich equation, however, presupposes that the response of tissue energy retention to increments in MEI obeys the law of diminishing returns over all intake levels, which precludes an increasing slope over any segment of the response curve. To address this potential problem, France et al. (1989) proposed some sigmoidal or Sshaped functions for situations in which the law of diminishing returns does not apply to the rate of energy retention across the range described.

The objectives of the present study are to collate data from energy balance studies with lactating dairy cows, and to evaluate alternative mathematical functions to estimate parameters of energy metabolism in relation to milk production such as $k_{l}, k_{g}, k_{t}, k_{m}$, and $\mathrm{ME}_{\mathrm{m}}$. The approach utilizes linear and nonlinear models to estimate $\mathrm{ME}$ requirement for maintenance and the efficiency of utilization of ME for milk production and includes a novel method to determine the efficiency of utilization of $\mathrm{ME}$ for tissue energy during lactation and the efficiency of utilization of body stores for milk production. The results from the alternative approach are then compared with traditional methods of analysis. The null hypothesis was that the relationship between MEI and milk energy is linear after correcting for tissue energy utilization and energy gain.

\section{MATERIALS AND METHODS}

\section{The Database}

A database containing energy balance data for 652 dairy cow observations was assembled from calorimetry studies conducted at the Centre for Dairy Research (CEDAR) at the University of Reading, the Agricultural Research Institute for Northern Ireland (ARINI), Queens University of Belfast and Grassland Research Institute, Hurley. Table 1 shows details of diet composition of the trials used to construct the database. The range of calorimetric data included in database is summarized in Table 2.

\section{Mathematical Considerations}

New approach. We define the efficiency of utilization of ME for milk energy, $k_{l}$, as the derivative:

$$
\begin{gathered}
k_{l}= \\
\mathrm{d}(\text { Milk energy derived from MEI)/ } \\
\mathrm{d}(\text { MEI directed towards maintenance } \\
\text { and milk production) }
\end{gathered}
$$

Based on this definition, $k_{l}$ can be found by plotting milk energy derived from MEI ( $y$-axis, MJ/kg of $\mathrm{BW}^{0.75}$ per day) against MEI directed towards maintenance and milk production ( $x$-axis, MJ/kg of $\mathrm{BW}^{0.75}$ per day) and finding the slope of the graph over the region where each increment in MEI is directed towards milk production (see Figure 1). When the cow is in positive tissue energy balance, some of the MEI is being directed towards tissue energy retention and therefore MEI is corrected as follows:

$$
\text { Corrected MEI, } x=\mathrm{MEI}-|\mathrm{TE}| / k_{g}
$$

where |TE| denotes the magnitude of the tissue energy retention and $k_{g}$ is the efficiency of utilization of MEI for tissue energy growth. A book value for $k_{g}$ is 0.60 assuming a metabolizability ([ME]/[Gross energy]) of diet of 0.6 (AFRC, 1993). When the cow is in zero energy balance, all the MEI is being directed to maintenance and milk production and no correction is needed. When the cow is in negative energy balance, some of the milk energy $\left(\mathbf{E}_{\mathbf{l}}, \mathrm{MJ} / \mathrm{kg}\right.$ of $\mathrm{BW}^{0.75}$ per day) is derived from body stores and therefore $\mathrm{E}_{1}$ is corrected as follows:

$$
\text { Corrected } \mathrm{E}_{1}, y=\mathrm{E}_{1}-|\mathrm{TE}| \times k_{t}
$$


Table 1. Diet composition and references (where applicable) of the trials used to construct the database. The trials were conducted at the Centre for Dairy Research (CEDAR), Agricultural Research Institute of Northern Ireland (ARINI), Queens University of Belfast (Queens) and Grassland Research Institute, Hurley (Hurley).

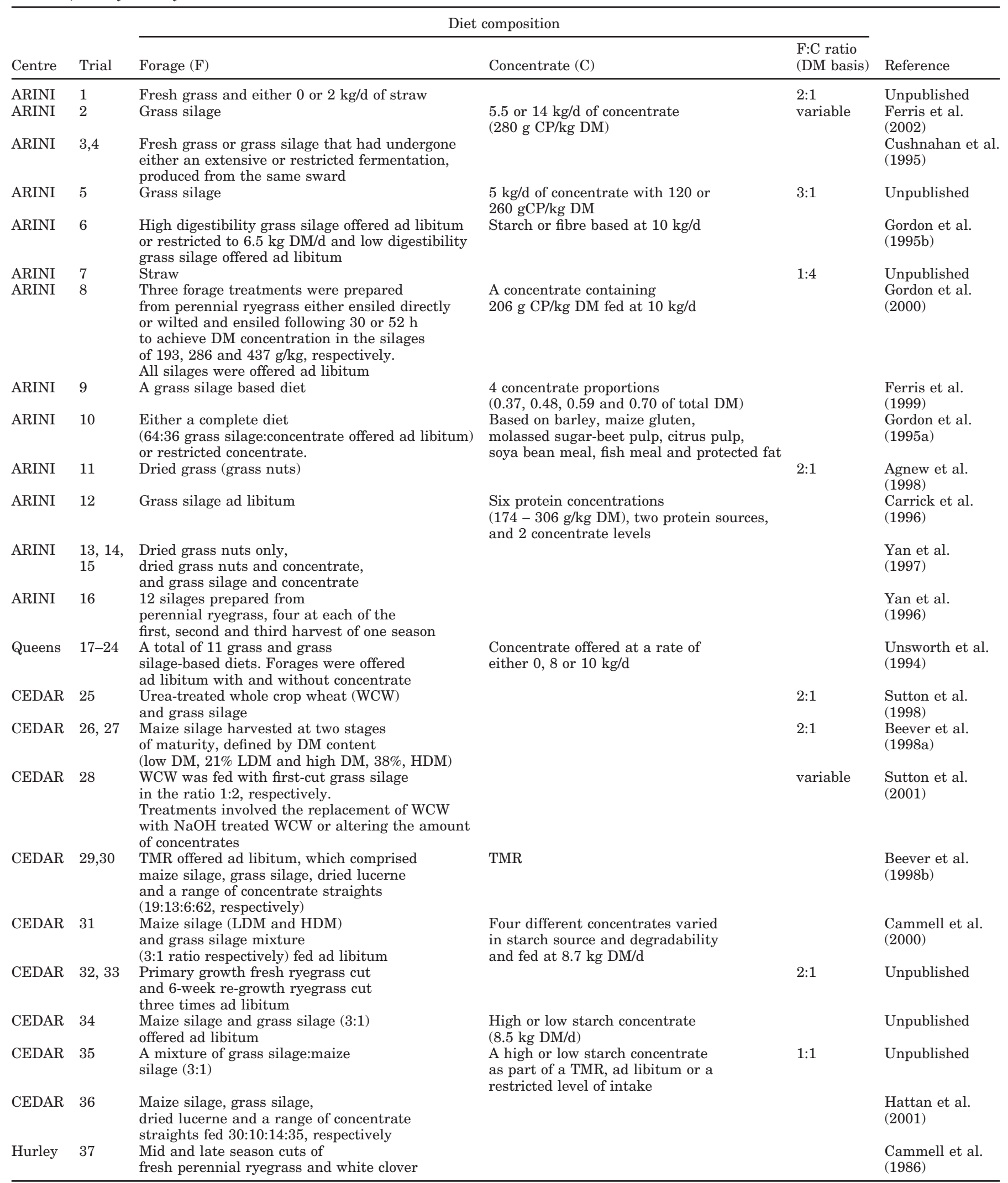


Table 2. Summary statistics of the calorimetric data used in the study.

\begin{tabular}{lcccc}
\hline & Mean & $\begin{array}{l}\text { Standard } \\
\text { deviation }\end{array}$ & Minimum & Maximum \\
\hline Animal data & & & & \\
DMI (kg/d) & 17.4 & 3.97 & 6.61 & 27.7 \\
Forage proportion & 0.60 & 0.21 & 0.10 & 1.00 \\
Milk yield (kg/d) & 24.7 & 9.13 & 0.93 & 59.7 \\
Live weight (kg) & 579 & 70.9 & 385 & 826 \\
Energy measurements (MJ/d) & & & & 543 \\
Gross energy & 330 & 29.5 & 123 & 169 \\
Fecal energy & 88.6 & 3.60 & 28.4 & 26.7 \\
Urinary energy & 12.1 & 4.79 & 7.98 & 34.3 \\
Methane & 21.7 & 25.5 & 67.9 & 255 \\
Heat production & 125 & 28.6 & 2.79 & 160 \\
Milk energy & 79.5 & 22.0 & -80.1 & 83.9 \\
Retained energy & 2.82 & 49.3 & 75.7 & 347 \\
ME intake & 207 & & & \\
\hline
\end{tabular}

where $k_{t}$ is efficiency of utilization of tissue energy for milk production. A book value for $k_{t}$ is 0.84 (AFRC, 1993). If, for example, $0.7 \mathrm{MJ} / \mathrm{d}$ of body stores are depleted and efficiency of tissue energy conversion to $\mathrm{E}_{1}$ is assumed as 0.84 , and $3.3 \mathrm{MJ} / \mathrm{d}$ of milk produced, $2.7 \mathrm{MJ} / \mathrm{d}(3.3-0.7 \times 0.84)$ are directed towards milk production and a $y$-value of $2.7 \mathrm{MJ} / \mathrm{d}$ is entered on the graph for this observation.

Let $y$ be regressed on $x$ using the general equation:

$$
y=f(x)+\varepsilon
$$

where $\varepsilon$ is an error term. The efficiency $k_{l}$, defined by equation [1] is then given by:

$$
k_{l}=\mathrm{d} y / \mathrm{d} x, y>0
$$

and the average efficiency $\left(\bar{k}_{l}\right)$ between maintenance and $N$ times maintenance $(N>1)$ given by:

$$
\begin{array}{r}
\int_{\bar{k}_{l}=} \frac{\int_{\left(\mathrm{ME}_{\mathrm{m}}\right.}^{N-1) \times \mathrm{ME}_{\mathrm{m}}}}{(N-\mathrm{d} x}=\frac{\int_{\mathrm{ME}_{\mathrm{m}}} \frac{\mathrm{d} y}{\mathrm{~d} x} \mathrm{~d} x}{(N-1) \times \mathrm{ME}_{\mathrm{m}}} \\
=\frac{\int_{0}^{N\left(N \times \mathrm{ME}_{\mathrm{m}}\right)}}{(N-1) \times \mathrm{ME}_{\mathrm{m}}}=\frac{y\left(N \times \mathrm{ME}_{\mathrm{m}}\right)}{(N-1) \times \mathrm{ME}_{\mathrm{m}}}
\end{array}
$$

where $\mathrm{ME}_{\mathrm{m}}$ denotes the value of $x$ at $y=0$, i.e., at maintenance. For example, if $f(x)$ is a straight line, then:

$$
\begin{gathered}
y=a x-b \\
\mathrm{~d} y / \mathrm{d} x=a
\end{gathered}
$$

$$
\int_{\bar{k}_{l}}=\frac{\int_{\mathrm{ME}_{\mathrm{m}}}^{N \times \mathrm{ME}_{\mathrm{m}}} a \mathrm{~d} x}{(N-1) \times \mathrm{ME}_{\mathrm{m}}}=a
$$

i.e., the average efficiency is the slope of the line.

In addition to the conventional straight line, we investigate the Mitscherlich, rectangular hyperbola (both of which exhibit diminishing returns behavior), Gompertz and logistic (both sigmoidal) as candidates for $f(x)$. The functional forms adopted, together with formulae for $\mathrm{ME}_{\mathrm{m}}$, are given in Table 3. In the nonlinear models, the entities $a, b$, and $c$ are positive parameters, and:

$$
\begin{gathered}
y_{\max }=a \\
y_{\text {min }}=-b
\end{gathered}
$$

The procedure for estimating $k_{g}$ and $k_{t}$ is as follows: rather than assume book values, we determine $k_{g}$ and $k_{t}$ from the database based on the principles expressed in equations [2] and [3]. For example, for the straight line candidate function, the following equation was fitted to the dataset:

$$
\mathrm{E}_{1}=a+b\left[\mathrm{MEI}-\left(\mathrm{T}_{\mathrm{g}} / k_{g}\right)\right]+\left(\mathrm{T}_{1} \times k_{t}\right)+\varepsilon
$$

where $\mathbf{T}_{\mathbf{g}}$ and $\mathbf{T}_{\mathbf{l}}$ are tissue gain and loss, respectively (both $\mathrm{MJ} / \mathrm{kg}$ of $\mathrm{BW}^{0.75}$ per day).

The dataset contained information collected from several experiments conducted at four sites, and in some instances multiple observations were made on the same cow at different periods. Therefore, fixed effects of research center and random effects of experiments (because the trials represent a random sample of a larger population), cows and period within experiments were added to the model. PROC MIXED procedure in SAS (Littell et al., 1996; SAS, 2000) was used for analysis. 
Table 3. Function forms used to describe the utilization of ME intake for milk production.

\begin{tabular}{lll}
\hline Candidate function & $f(x)$ & $\mathrm{ME}_{\mathrm{m}}$ \\
\hline Straight line & $a x-b$ & $\mathrm{~b} / \mathrm{a}$ \\
Mitscherlich & $a-(a+b) \mathrm{e}^{-c x}$ & $c^{-1} \ln [(a+b) / a]$ \\
Rectangular hyperbola & $(a+b) x /(c+x)-b$ & $b c / a$ \\
Gompertz & $b \exp \left[\left(1-\mathrm{e}^{-c x}\right) \ln \frac{a+2 b}{b}\right]-2 b$ & $c^{-1} \ln \left\{\frac{\ln [(a+2 b) / b]}{\ln [(a+2 b) /(2 b)]}\right\}$ \\
Logistic & $\frac{b(a+2 b)}{b+(a+b) \mathrm{e}^{-c x}}-2 b$ & $c^{-1} \ln [2(a+b) / a]$ \\
\hline
\end{tabular}

The results showed that there were no significant effects of cow and period $(P>0.20)$ and, therefore, random effects of cow and period were removed from subsequent analysis. The four other functional forms were also transformed to an expression similar to equation [12] and fitted to the dataset using the nonlinear mixed procedure (PROC NLMIXED in SAS, SAS, 2000) to optimize the parameter estimates.

Yan et al. (1997) using 12 nonpregnant lactating Holstein-Friesian cows offered forage-based diets experimentally determined the fasting heat production, $\mathrm{F}$, of the cows to be 0.453 (SD 0.0354) $\mathrm{MJ} / \mathrm{kg}$ of $\mathrm{BW}^{0.75}$ per day. This value is higher than the value adopted by NRC (2001), which is $0.335 \mathrm{MJ} / \mathrm{kg}$ of $\mathrm{BW}^{0.75}$ per day. Bayesian methods were used to merge the information from a prior estimate of the intercept $(0.453, \mathrm{SD} 0.0354)$ with that suggested by the data. A weighted average of the prior and observed estimates of the intercept was calculated by using the reciprocals of their respective variances as the weights. All the functions were fitted to the dataset by assigning the Bayesian estimate, parameter $b$, and the results compared with those obtained from unconstrained fitting.

Classical approach. Historically, energy balance data from lactating dairy cows were analyzed using the classical multiple linear regression approach of Moe et al. (1971):

$$
\mathrm{MEI}=a+\beta_{1} \mathrm{MBW}+\beta_{2} \mathrm{E}_{1}+\beta_{3} \mathrm{~T}_{\mathrm{g}}+\beta_{4} \mathrm{~T}_{1}+\varepsilon
$$

where MEI is ME intake (MJ/d), MBW is metabolic BW ( $\mathrm{kg}$ of $\left.\mathrm{BW}^{0.75}\right), \mathrm{E}_{\mathrm{l}}$ is energy in milk $(\mathrm{MJ} / \mathrm{d}), \mathrm{T}_{\mathrm{g}}$ is tissue gain $(\mathrm{MJ} / \mathrm{d})$, and $\mathrm{T}_{1}$ is tissue loss $(\mathrm{MJ} / \mathrm{d}) . a$ is the regression constant which was assumed to represent the amount of $\mathrm{ME}$ intake that was not attributable to any specific variable in the model, $\beta_{1}, \beta_{2}$, and $\beta_{3}$ represent the unit amount of ME required for maintenance, milk production, and body gain, respectively, $\beta_{4}$ is the amount of dietary ME, which is spared per unit of body tissue energy loss and $\varepsilon$ is error.

Based on efficiencies from equation [13], Moe et al. (1972) regressed net energy for lactation $(\mathrm{MJ} / \mathrm{kg}$ of
$\mathrm{BW}^{0.75}$ per day) against MEI ( $\mathrm{MJ} / \mathrm{kg}$ of $\mathrm{BW}^{0.75}$ per day) to calculate $k_{l}$ and $\mathrm{ME}_{\mathrm{m}}$. Net energy for lactation was calculated as follows:

$$
\begin{gathered}
\mathrm{NE}_{1}=\text { milk gross energy }+\left(\mathrm{T}_{\mathrm{g}} / 1.14\right) \\
-\left(0.84 \mathrm{~T}_{1}\right)+0.18 \text { fetal mass }+0.03 \text { excess } \mathrm{N}
\end{gathered}
$$

where excess $\mathrm{N}$ is the digestible $\mathrm{N}$ intake minus $\mathrm{N}$ in milk (with its efficiency of conversion, which was assumed to be 0.625 (milk N/0.625)), fetus and that used for maintenance.

In the United Kingdom, book values (from AFRC, 1993) of 0.60 and 0.84 are used for $k_{g}$ and $k_{t}$, respectively, to correct energy balance data from calorimetry experiments.

Three analyses were conducted using the classical approach. First, $k_{g}$ and $k_{t}$ values were estimated using multiple linear regression analysis (equation [13]). Second, $\mathrm{NE}_{1}$ was calculated and regressed against MEI using the $k_{g}$ and $k_{t}$ values of Moe et al. (1972). General linear regression procedure of Genstat (1992) was used to conduct both analyses. Finally, the data were corrected using $k_{g}$ and $k_{t}$ values of AFRC (1993) and a linear mixed model analysis carried out from which $k_{l}$ and $\mathrm{ME}_{\mathrm{m}}$ values were determined. The results of the above analyses were then compared with results for the alternative straight line (unconstrained, equation [12]) and Mitscherlich (constrained) models due to the superior fit of both of these models to our data based on Bayesian information criteria (BIC).

\section{RESULTS}

\section{Estimating Efficiency Coefficients $\boldsymbol{k}_{g}$ and $\boldsymbol{k}_{\boldsymbol{t}}$}

The efficiency coefficients $k_{g}$ and $k_{t}$ were estimated by fitting linear and nonlinear mixed models, corrected as equation [12], to the data (Table 4). In all cases, there was a good relationship between MEI and $\mathrm{E}_{1}(P$ $<0.001$ ). Based on BIC and standard error of the models, the straight line had the best fit to the data followed by the Gompertz and the diminishing returns functions. 

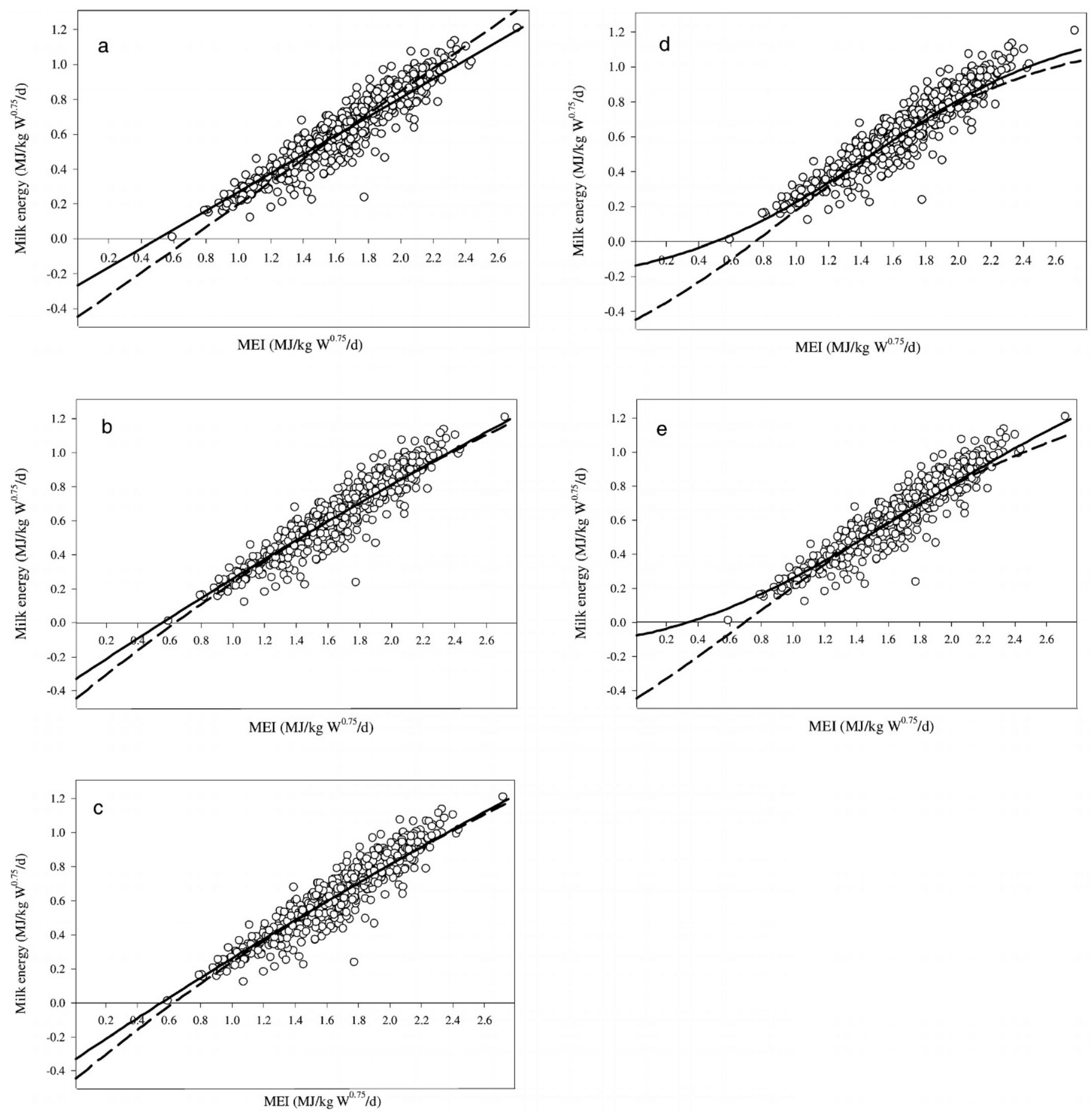

Figure 1. A relationship between metabolizable energy intake (MEI, MJ/kg of BW ${ }^{0.75}$ per day) and milk energy output (MJ/kg of BW ${ }^{0.75}$ per day) $(\mathrm{n}=652)$. Symbols represent observed values and the lines are regression lines fitted using (a) straight line (b) Mitscherlich (c) rectangular hyperbola (d) logistic and (e) Gompertz. Solid lines represent unconstrained fit and broken lines constrained fit of the models.

The range of estimates for $k_{g}$ across all functions was 0.83 to 0.86 (SE 0.028 and 0.029 , respectively) and $k_{t}$ was estimated to be 0.66 to 0.69 (SE 0.027 and 0.028 , respectively).

\section{Estimating $\overline{\boldsymbol{k}}_{\boldsymbol{I}}$}

The unconstrained fitting of the functions to the data showed that in all cases, there was a similar goodness 
Table 4. Parameter estimates and other measures when (a) unconstrained models were fitted to the data and (b) the intercept was constrained to a Bayesian estimate which was calculated by merging prior information of a measured fasting heat production value with that suggested by the data. Standard errors are given in brackets.

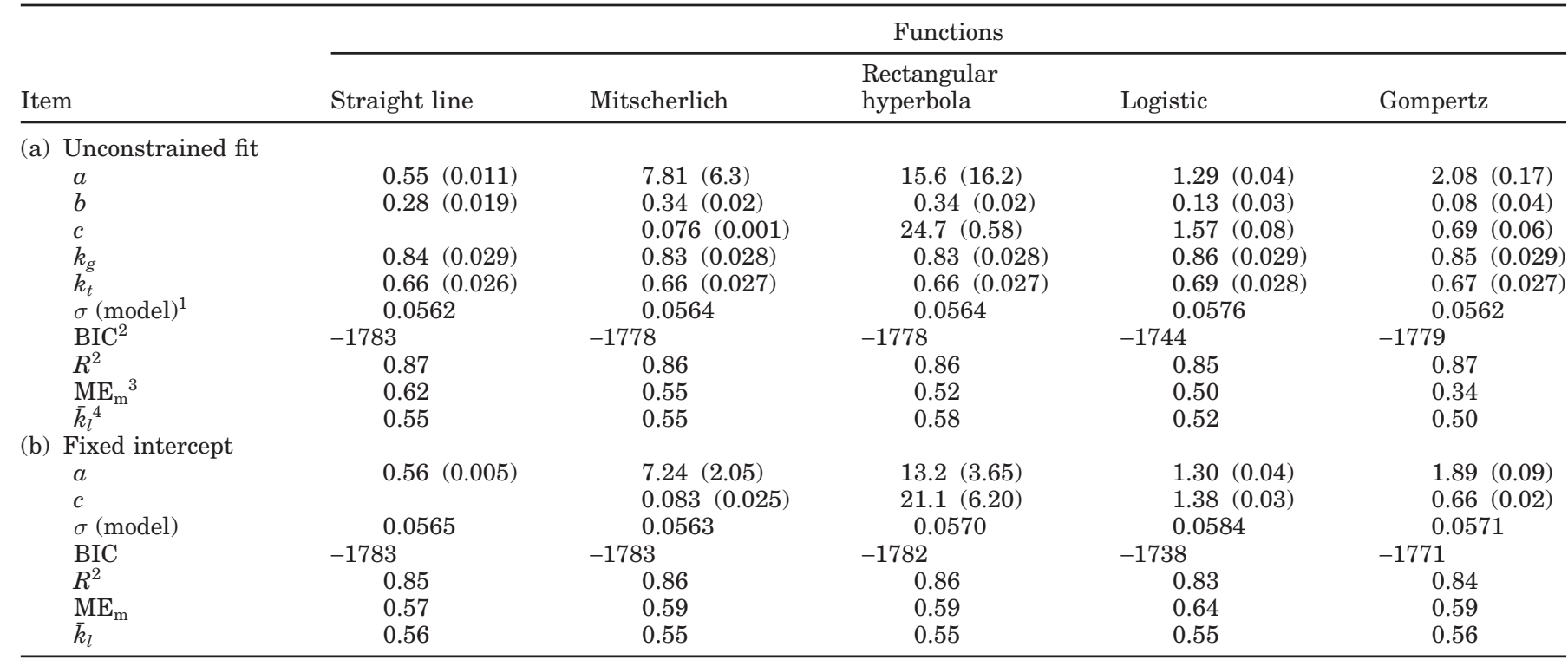

${ }^{1}$ Standard error of model $=\sqrt{ }$ variance $\left(\sigma^{2}\right)$ of error.

${ }^{2} \mathrm{BIC}=$ Bayesian information criteria (smaller value means a better model).

${ }^{3}$ The net energy requirement for maintenance $\left(\mathrm{ME}_{\mathrm{m}}, \mathrm{MJ} / \mathrm{kg} \mathrm{BW}{ }^{0.75}\right.$ per day) for the straight line was calculated according to $\mathrm{Moe}$ et al. (1972) and Reynolds and Tyrrell (2000) by first regressing milk energy ( $\mathrm{E}_{1}$ ) on MEI (values reported in the table) and then regressing MEI on $\mathrm{E}_{1}\left[\mathrm{MEI}=1.48(0.033) \mathrm{E}_{1} .+0.73(0.023)\right]$. The two estimates of $\mathrm{ME}_{\mathrm{m}}$ were then averaged.

${ }^{4}$ The average efficiency of utilization of MEI for milk production $\left(\bar{k}_{l}\right)$ for the non-linear functions was calculated by setting the upper limit to $2.4 \mathrm{MJ} / \mathrm{kg} \mathrm{W}^{0.75} / \mathrm{d}$.

of fit $\left(R^{2}>0.85\right)$ (Table 4). However, the straight line, due to its lowest BIC and SE of model, was the best fitting function. The diminishing returns functions indicated an over-parameterization as the estimates of the parameter $a$ were not significant. Although all the parameter estimates of the sigmoidal functions were significant $(P<0.01)$, they did not improve on the straight line fitting (Table 4). Based on the parameter estimates, $\mathrm{ME}_{\mathrm{m}}$ and $\bar{k}_{l}$ were calculated. $\mathrm{ME}_{\mathrm{m}}$ values ranged between 0.34 (Gompertz) to $0.62 \mathrm{MJ} / \mathrm{kg}$ of $\mathrm{BW}^{0.75}$ per day (straight line) and $\bar{k}_{l}$ from 0.50 (Gompertz) to 0.58 (rectangular hyperbola). Caution must be taken when comparing $\bar{k}_{l}$ because although the upper limit on all nonlinear functions when calculating $\bar{k}_{l}$ was fixed at $2.4 \mathrm{MJ} /$ $\mathrm{kg}$ of $\mathrm{BW}^{0.75}$ per day, this limit expressed as a multiple of estimated $\mathrm{ME}_{\mathrm{m}}$ varied across models because of the difference in estimated $\mathrm{ME}_{\mathrm{m}}$.

A Bayesian estimate (calculated by merging the experimentally determined value of $\mathrm{F}$ with that derived from the observations) was used to fix the parameter $b$ in all the functions when fitting to the data (Table 4, Figure 1). The over-parameterization problem of the diminishing returns functions was resolved with the introduction of the fixed parameter and the Mitscherlich and straight line showed the best fit to the data based on BIC and SE values. Some differences in $\mathrm{ME}_{\mathrm{m}}$ values were observed in the constrained fittings, which ranged from 0.57 (straight line) to $0.64 \mathrm{MJ} / \mathrm{kg}$ of $\mathrm{BW}^{0.75}$ per day (logistic). The $\bar{k}_{l}$ was very similar in all the constrained fittings (0.55) and also showed some differences compared to values from the unconstrained fittings.

\section{Classical Method of Analysis}

The same procedures and calculations as reported by Moe et al. (1972) were carried out on the CEDAR and ARINI data. The linear regression of $\mathrm{NE}_{1}$ on $\mathrm{ME}$ (both scaled to metabolic BW) had an intercept of $-0.408 \pm$ 0.027 and a slope of $0.628 \pm 0.015$ (Figure 2). The maintenance requirement of the cows was $0.65 \mathrm{MJ} \mathrm{ME} / \mathrm{kg}$ of $\mathrm{BW}^{0.75}$ per day. Based on dataset of similar size and Holstein-Friesian cows, Moe et al. (1972) reported a maintenance requirement of $0.49 \mathrm{MJ} \mathrm{ME} / \mathrm{kg}$ of $\mathrm{BW}^{0.75}$ per day. It is interesting to note that efficiency of utilization of MEI for milk was similar but there was a larger estimate of maintenance energy requirement with our data.

The analysis shown in Figure 2 was based on the $k_{g}$ and $k_{t}$ values of Moe et al. (1972) (0.75 and 0.82, 


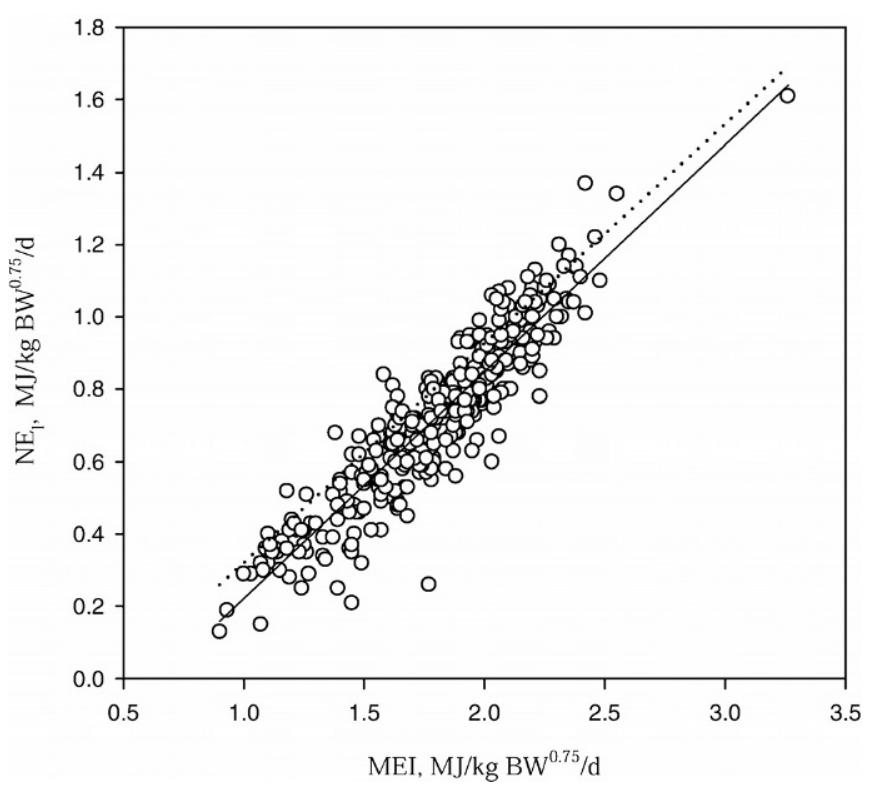

Figure 2. Net energy for lactation and ME intake according to Moe et al. (1972). The linear regressions shown are for the current dataset (solid) and the equation of Moe et al. (1972) (dotted).

respectively). These efficiencies were recalculated using the classical method of analysis (equation [13]) and the results are shown in Table 5.

Our data were analyzed using the AFRC (1993) book values for correcting energy balance data $\left(k_{g}=0.6, k_{t}\right.$ $=0.84)$. The linear mixed regression of the data gives an intercept of -0.21 (SE 0.021) and a slope of 0.50 (SE 0.02).

\section{DISCUSSION}

There have been various estimates of $k_{g}$ in lactating dairy cows in the literature (e.g., Moe et al., 1970; ARC,
1980). The value of $k_{g}$ recommended by ARC (1980) and adopted by AFRC (1993) is linked to feed quality and $k_{l}\left(k_{g}=0.61\right.$ assuming a feed quality of $12 \mathrm{MJ} / \mathrm{kg} \mathrm{DM}$ of ME and $18.8 \mathrm{MJ} / \mathrm{kg} \mathrm{DM}$ of gross energy). According to ARC (1980) and AFRC (1993), energy is used for body gain with almost the same efficiency as for milk production. On the other hand, NRC (2001) adopts the value of Moe et al. (1971) who reported that a metabolic change of lactation increases $k_{g}$ from 0.60 in nonlactating cows to $0.75 \pm 0.024$ in lactating cows. Reynolds and Tyrrell (2000) quoted Armstrong and Blaxter (1965) that part of the reason for the $25 \%$ increase in efficiency could be the result of the use of acetate for milk synthesis rather than for oxidation in lactating cows. All the functions used in this study have consistently estimated $k_{g}$ to be about $0.84(\mathrm{SE}=0.028)$, which is closer to the value reported by Moe et al. (1971). It has been reported that efficiency of utilization of MEI for body energy gain is affected by level of MEI, stage of lactation, and genetic potential (Moe and Tyrrell, 1975). Therefore, some of the reasons for the small differences in $k_{g}$ between this study and Moe et al. (1971) could be due to differences in methods of analysis, genetic potential of the cows or just randomness.

The values of $k_{t}$ in this study (Table 5) are widely different from recommendations of ARC (1990), AFRC (1993) of 0.84 and NRC (2001) of 0.82, which was based on the Moe et al. (1971) estimate of $0.82 \pm 0.022$. AFRC (1990) seems to misquote ARC (1980) giving the value of $k_{t}$ as $k_{l} / 0.80$ (=0.79 assuming $q_{m}$ is 0.6 ). The $k_{t}$ from this study were much lower than previous recommendations and even when estimated using multiple linear regression (equation [13]), the value of $k_{t}$ was very close to estimates using the new method of analysis (Table 5). One of the fundamental differences between the British national recommendation and this study is the nature

Table 5. Comparison of key parameters currently recommended for use in calculating energy requirement of dairy cows and the new method of analysis. The parameters are the average efficiency of utilization of metabolizable energy intake for milk production $\left(\bar{k}_{l}\right)$ and body gain $\left(k_{g}\right)$, efficiency of utilization of tissue energy for milk production $\left(k_{t}\right)$ and maintenance energy requirement $\left(\mathrm{ME}_{\mathrm{m}}, \mathrm{MJ} / \mathrm{kg}^{0.75}\right.$ of $\mathrm{BW}$ per day). From the alternative functions, the unconstrained straight line and constrained (fixed intercept) Mitscherlich were chosen for comparison with currently used values.

\begin{tabular}{|c|c|c|c|c|c|c|}
\hline & \multicolumn{2}{|c|}{ Recommended } & \multicolumn{4}{|c|}{ Our data } \\
\hline & $\begin{array}{l}\text { AFRC } \\
(1993)\end{array}$ & $\begin{array}{l}\text { NRC } \\
(2001)^{1}\end{array}$ & $\begin{array}{l}\text { AFRC } \\
(1993)^{2}\end{array}$ & $\begin{array}{l}\text { Moe et al. } \\
(1971)^{3}\end{array}$ & Straight line & Mitscherlich \\
\hline$k_{g}$ & 0.60 & 0.75 & & $0.86(0.066)$ & $0.84(0.029)$ & $0.83(0.028)$ \\
\hline$k_{t}$ & 0.84 & 0.82 & & $0.68(0.076)$ & $0.66(0.026)$ & $0.66(0.027)$ \\
\hline $\mathrm{ME}_{\mathrm{m}}$ & 0.49 & 0.51 & 0.42 & $0.69(0.075)$ & 0.62 & 0.59 \\
\hline $\bar{k}_{l}$ & 0.62 & 0.64 & $0.50(0.02)$ & $0.68(0.022)$ & 0.55 & 0.55 \\
\hline$\sigma^{4}$ & & & 0.0659 & 0.1216 & 0.0562 & 0.0563 \\
\hline
\end{tabular}

${ }^{1} \mathrm{NRC}(2001)$ recommendations are based on Moe et al. (1971).

${ }^{2}$ Our data was corrected using the AFRC (1993) efficiency values and a linear mixed model fitted.

${ }^{3}$ Equation [13] was fitted to our data.

${ }^{4}$ Standard error of model $=\sqrt{ }$ variance $\left(\sigma^{2}\right)$ of residual error. 
of the data used for the analysis. In the former, BW change was used as a measure of energy balance and it was assumed that BW change is directly proportional to energy balance while the later used calorimetric measurements of energy balance. There is some evidence (Flatt et al., 1969) that cows can be in negative energy balance without BW change. Therefore, the estimated $k_{t}$ is biased upward if BW loss is used as a proxy for energy balance. Moe et al. (1971) also warned that differences in rumen fill and water replacing body fat utilized may mask live weight changes when the cow is in negative energy retention.

Using the classical method of analysis to estimate efficiencies from our dataset gave a considerably different result to that recommended by the British and American national research councils (Table 5). This indicates that there is a need to re-evaluate efficiencies and maintenance requirements for lactating dairy cows.

When the data were corrected using the new approach and the five functions that were specially parameterized for energy balance analysis were fitted, similar goodness of fit $\left(R^{2}\right)$ values were obtained (Table 4$)$. The same was true when the data were fitted either using a fixed value for the parameter $b$ or without any constraint. The diminishing returns functions produced a large standard error for one of the parameter estimates during unconstrained fitting. The logistic and Gompertz showed much lower and significant standard errors for all three parameters estimated. The Gompertz was slightly better when the BIC and SE of model were considered, perhaps because of the nonsymmetrical nature of the curve when compared to the logistic function. Using previous knowledge of fasting heat metabolism to fix one of the parameters $(b)$ reduced over-parameterization problems and the Mitscherlich showed a significant estimate of the theoretical maximum value of milk energy production $(a)$. Biologically, it is more likely that the efficiency of conversion of MEI is higher when cows consume energy below their maintenance requirements (e.g., Blaxter and Boyne, 1978; AFRC, 1993) and decreases as the intake level increases, which is described by the Mitscherlich but not always the case with Gompertz and logistic (Table 4, Figure 1). The Mitscherlich has been used in energy balance studies before, e.g., Blaxter and Boyne (1978) used the function to describe the relationship between the rate of feed intake and the efficiency of utilization of gross energy for body gain in growing ruminants. Scarcity of observations approaching the asymptote makes the estimation of the parameter $a$ (maximum milk energy) difficult. However, in estimating the maintenance requirement and energy efficiencies, precision of the parameter estimate for $a$ is less relevant.
Estimates of maintenance requirement using the alternative approach (Table 4), traditional multiple regression analysis (Table 5) and analyzing data by correcting for $k_{g}$ and $k_{t}$ according to Moe et al. (1971) indicate that the value was constantly higher than in previous reports. Part of the reason could be genetic differences of cows used in this study compared with those in late 1960's and early 1970's. Another factor may be differences in type of diet fed to the cows. Preliminary analysis shows that cows fed dried grass had lower maintenance requirements than those fed maize silage-based diets, which was the major feed component in the experiments conducted at the University of Reading.

The $\bar{k}_{l}$ was lower in calculations from the best fit functions compared with recommended values (Table 5). The straight line model assumes that there is no change in $k_{l}$ as the feeding level increases. The other functions allow the possibility of $k_{l}$ changing with level of feeding and the diminishing returns functions predict a higher $k_{l}$ at a lower MEI. However, although it might be biologically sensible, there is no statistical reason to suggest that feeding level affects $k_{l}$.

\section{CONCLUSION}

Our analysis of energy balance data shows considerable differences in estimates of efficiencies of energy conversion compared with previous analyses. The fact that using the same methodology led to large differences suggests that those recommendations made 30 yr ago may need to be revised. In an unconstrained fit, the nonlinear models did not improve the variation accounted for by the straight line. However, when the Bayesian estimate of the intercept was used, fitting the Mitscherlich to the data accounted for variation better than any of the other constrained functions, but marginally less than the unconstrained straight line that represented the null hypothesis in this set of analyses. The parameter estimates were significant and made biological sense. The Mitscherlich gave higher estimates of $k_{m}$ compared with $k_{l}$ and both efficiencies (and $\mathrm{ME}_{\mathrm{m}}$ ) can be estimated from a single equation that provides the possibility of investigating the relationship between $k_{l}$ and level of feeding. Based on the best fit models, $\mathrm{ME}_{\mathrm{m}}$ values were 0.62 and $0.59 \mathrm{MJ} / \mathrm{kg}^{0.75} / \mathrm{d}$ (for the unconstrained straight line and constrained Mitscherlich, respectively) and $\bar{k}_{l}$ was 0.55 for both functions. To test conclusively whether milk energy is related to MEI linearly or not, data from high yielding dairy cows (with energy intakes of more than $2.4 \mathrm{MJ} /$ $\mathrm{kg} \mathrm{W}^{0.75}$ per day) are required. 


\section{ACKNOWLEDGMENTS}

This study was partially funded by the Department for Environment, Food and Rural Affairs, the Milk Development Council and a consortium of industrial partners within a LINK Sustainable Livestock Production project: Feed into Milk. The authors thank the late G. Alderman for his contribution to the work, J. L. Corbett for discussions on energy metabolism and M. Denham for statistical advice.

\section{REFERENCES}

Agnew, R. E., and T. Yan. 2000. Impact of recent research on energy feeding systems for dairy cattle. Livest. Prod. Sci. 66:197-215.

Agnew, R. E., T. Yan, and F. J. Gordon. 1998. Nutrition of the high genetic merit dairy cow-energy metabolism studies. Pages 181208 in Recent Advances in Animal Nutrition, Nottingham University Press, Nottingham, U.K.

Agricultural and Food Research Council. 1990. Technical Committee on Responses to Nutrients, Report 5. Nutrient Requirements of Ruminant Animals: Energy. Nutr. Abst. Rev. Ser. B 60:729-804.

Agricultural and Food Research Council. 1993. Energy and Protein Requirements of Ruminants. CAB International, Wallingford, U.K.

Agricultural Research Council. 1965. The Nutrient Requirements of Farm Livestock, Volume \#2, Ruminants. HMSO, London, U.K.

Agricultural Research Council. 1980. The Nutrient Requirements of Ruminant Livestock, Technical Review. CAB, Farnham Royal, U.K.

Beever, D. E., S. B. Cammell, J. D. Sutton, and D. J. Humphries. 1998a. The effect of stage of harvest of maize silage on the concentration and efficiency of utilisation of metabolisable energy by lactating cows. Pages 359-362 in Energy Metabolism of Farm Animals, CAB International, Wallingford, U.K.

Beever, D. E., S. B. Cammell, J. D. Sutton, N. Rowe, and G. E. Perrott. 1998b. Energy metabolism in high yielding cows. Page 13 in Proc. Brit. Soc. Anim. Sci., Scarborough, U.K.

Blaxter, K. L. 1962. The Energy Metabolism of Ruminants. Charles C. Thomas, Springfield, IL.

Blaxter, K. L., and F. W. Wainman. 1961. The utilisation of food by sheep and cattle. J. Agric. Sci. (Camb.) 57:419-425.

Blaxter, K. L., and W. A. Boyne. 1978. The estimation of the nutritive value of feeds as energy sources for ruminants and the derivation of feeding systems. J. Agric. Sci. (Camb.) 90:47-68.

Cammell, S. B., J. D. Sutton, D. E. Beever, D. J. Humphries, and R. H. Phipps. 2000. The effect of crop maturity on the nutritional value of maize silage for lactating dairy cows. Part I. Energy and nitrogen utilisation. Anim. Sci. 71:381-390.

Cammell, S. B., D. J. Thompson, D. E. Beever, M. J. Haines, M. S. Dhanoa, and M. C. Spooner. 1986. The efficiency of energy utilisation in growing cattle consuming fresh perennial rye grass (Lolium perenne cv. Melle) or white clover (Trifolium repens $\mathrm{cv}$. Blanca). Br. J. Nutr. 55:669-680.

Carrick, I. M., D. C. Patterson, F. J. Gordon, and C. S. Mayne. 1996 The effect of quality and level of protein on the performance of dairy cattle of differing genetic merits. Anim. Sci. 62:642. (Abstr.)

Cushnahan, A., C. S. Mayne, and E. F. Unsworth. 1995. Effects of ensilage of grass on performance and nutrient utilisation by dairy cattle. 2. Nutrient metabolism and rumen fermentation. Anim. Sci. 60:347-359.

Ferris, C. P., M. A. McCoy, S. D. Lennox, D. C. Catney, and F. J. Gordon. 2002. Nutrient utilisation and energy balance associated with two contrasting winter milk production systems for high genetic merit autumn calving dairy cows. Ir. J. Agric. Food Res. 41:55-70.
Ferris, C. P., F. J. Gordon, D. C. Patterson, M. G. Porter, and T. Yan. 1999. The effect of genetic merit and concentrate proportion in the diet on nutrient utilisation by lactating dairy cows. J. Agric. Sci. 132:483-490.

Flatt, W. P., P. W. Moe, R. R. Oltjen, P. A. Putnam, and N. W. Hooven, Jr. 1969. Energy utilization by high producing dairy cows. II. Summary of energy balance experiments with lactating Holstein cows. Page 109 in Proc. 4th Symp. Energy Metabolism. EAAP Publication no. 12, Newcastle Upon Tyne, U.K.

France, J., M. S. Dhanoa, S. B. Cammell, M. Gill, D. E. Beever, and J. H. M. Thornley. 1989. On the use of response functions in energy balance analysis. J. Theor. Biol. 140:83-99.

Genstat 5 Committee. 1992. Genstat 5 Reference Manual. Oxford University Press, Oxford, U.K.

Gordon, F. J., D. C. Patterson, M. G. Porter, and E. F. Unsworth. 2000. The effect of degree of grass wilting prior to ensiling on performance and energy utilisation by lactating dairy cattle. Livest. Prod. Sci. 64:291-294.

Gordon, F. J., D. C. Patterson, T. Yan, M. G. Porter, C. S. Mayne, and E. F. Unsworth. 1995a. The influence of genetic index for milk production on the response to complete diet feeding and the utilisation of energy and nitrogen. Anim. Sci. 61:199-210.

Gordon, F. J., M. G. Porter, C. S. Mayne, E. F. Unsworth, and D. J. Kilpatrick. 1995b. The effect of forage digestibility and type of concentrate on nutrient utilisation for lactating dairy cattle. J. Dairy Res. 62:15-27.

Hattan, A. J., D. E. Beever, S. B. Cammell, and J. D. Sutton. 2001. Energy utilisation in high-yielding cows during early lactation. Pages 325-328 in Energy Metabolism of Farm Animals, EAAP Publication no. 103, Wageningen Pers, Wageningen, The Netherlands.

Littell, R. C., G. A. Milliken, W. W. Straub, and R. D. Wolfinger. 1996. SAS System for Mixed Models. SAS Inst., Cary, NC.

Moe, P. W., and H. F. Tyrrell. 1975. Efficiency of conversion of digested energy to milk. J. Dairy Sci. 58:602-610.

Moe, P. W., H. F. Tyrrell, and W. P. Flatt. 1970. Partial efficiency of energy use for maintenance, lactation, body gain and gestation in the dairy cow. Pages 65-68 in Energy Metabolism of Farm Animals, EAAP Publication no. 13, Juris Verlag, Zurich, Switzerland.

Moe, P. W., H. F. Tyrrell, and W. P. Flatt. 1971. Energetics of body tissue mobilization. J. Dairy Sci. 54:548-553.

Moe, P. W., W. P. Flatt, and H. F. Tyrrell. 1972. Net energy value of feeds for lactation. J. Dairy Sci. 55:945-958.

National Research Council. 2001. Nutrient Requirements of Dairy Cattle. 7th rev. ed. Natl. Acad. Press, Washington, DC.

Reynolds, C. K., and H. F. Tyrrell. 2000. Energy metabolism in lactating beef heifers. J. Anim. Sci. 78:2696-2705.

SAS/STAT User's Guide, Version 8 Edition. 2000. SAS Inst., Inc., Cary, NC.

Sutton, J. D., R. H. Phipps, S. B. Cammell, and D. J. Humphries. 2001. Attempts to improve the utilisation of urea-treated wholecrop wheat by lactating dairy cows. Anim. Sci. 73:137-147.

Sutton, J. D., S. B. Cammell, D. E. Beever, D. J. Humphries, and R. H. Phipps. 1998. Energy and nitrogen balance of lactating dairy cows given mixtures of urea-treated whole-crop wheat and grass silage. Anim. Sci. 67:203-212.

Unsworth, E. F., C. S. Mayne, A. Cushnahan, and F. J. Gordon. 1994. The energy utilisation of grass silage diets by lactating dairy cows. Pages 179-181 in Energy Metabolism of Farm Animals, EAAP Publication No. 76, Mojacar, Spain.

Yan, T., D. C. Patterson, F. J. Gordon, and M. G. Porter. 1996. The effects of wilting of grass prior to ensiling on the response to bacterial inoculation. 1. Silage fermentation and nutrient utilisation over three harvests. Anim. Sci. 62:405-417.

Yan, T., F. J. Gordon, C. P. Ferris, R. E. Agnew, M. G. Porter, and D. C. Patterson. 1997. The fasting heat production and effect of lactation on energy utilisation by dairy cows offered forage-based diets. Livest. Prod. Sci. 52:177-186. 